\title{
Kriteria Buku Referensi Media Pembelajaran Matematika yang Diperlukan Bagi Guru-Guru SMP di Mataram
}

\section{Sripatmi*, Syahrul Azmi, Junaidi, Nourma Pramestie Wulandari, Ulfa Lu'luilmaknun}

Pendidikan Matematika, FKIP, Universitas Mataram, Mataram

spatmi@gmail.com

\begin{abstract}
The purpose of this study was to determine the criteria for a mathematics learning media reference book that is needed for junior high school mathematics teachers in the city of Mataram. The research begins with a survey on whether learning mathematics requires media, then identifies the frequency with which teachers use media in learning mathematics, as well as the reasons teachers never or rarely use media in learning mathematics. Based on the survey, it was found that teachers need reference books to develop mathematics learning media, so it is necessary to develop the criteria for the required reference books. Furthermore, a literature review was conducted to compare the needs (ideal conditions) for learning media reference books with the current state (real conditions). Conclusion The results of the study show that the materials that require media are: arithmetic operations Integers and fractions, linear equations, sets and venn diagrams, geometry, function values, function graph sketches, slopes of lines, Pythagoras, circles, tangents, inner circles and the outer circle of a triangle, the properties of geometric figures, similarity, congruence, cylinders, cones, and spheres. In addition, the media needed are concept maps, informative power points, interactive power points, student worksheets, learning videos, teaching aids, and GeoGebra. Furthermore, the criteria for a valid book were developed based on the results of the study which included 4 aspects, namely material aspects, language, presentation of material, and graphics.
\end{abstract}

Keywords: learning media; validity of reference books; student understanding

\begin{abstract}
Abstrak
Tujuan dari penelitian ini adalah mengetahui kriteria buku referensi media pembelajaran matematika yang diperlukan bagi guru matematika SMP dikota Mataram. Penelitian diawali dengan dilakukan survay tentang apakah pembelajaran matematika memerlukan media, kemudian mengidentifikasi frekuensi guru-guru dalam menggunakan media dalam pembelajaran matematika, serta alasan guru tidak pernah atau jarang menggunakan media dalam pembelajaran matematika. Berdasarkan survay ditemukan bahwa guru memerlukan buku referensi untuk mengembangkan media pembelajaran matematika sehingga perlu dikembangkan kriteria buku referensi yang diperlukan. Selanjutnya dilakukan kajian literatur untuk membandingkan kebutuhan (kondisi ideal) buku referensi media pembelajaran dengan keadaan (kondisi nyata) saat ini. Kesimpulan Hasil dari kajian diperoleh bahwa materi-materi yang memerlukan media adalah: operasi hitung bilangan bulat dan pecahan, persamaan linear, himpunan dan diagram venn, geometri, nilai fungsi, sketsa grafik fungsi, kemiringan garis, pythagoras, lingkaran, garis singgung, lingkaran dalam dan lingkaran luar segitiga, sifat-sifat bangun ruang, kesebangunan, kekongruenan, tabung, kerucut, dan bola. Selain itu media-media yang diperlukan adalah peta konsep, power point informatif, power point interaktif, lembar kerja
\end{abstract}


peserta didik, video pembelajaran, alat peraga, dan Geogebra. Selanjutnya dikembangkan kriteria buku yang valid berdasarkan hasil kajian yaitu mencakup 4 aspek yaitu aspek materi, bahasa, penyajian materi, dan kegrafikan.

Kata Kunci: media pembelajaran, validitas buku referensi; pemahaman siswa

\section{PENDAHULUAN}

Matematika adalah pelajaran yang sulit bagi siswa maupun mahasiswa. Sripatmi (2018) menyatakan pemahaman matematika mahasiswa berada pada kategori kurang sekali. Pemahaman matematika yang dimaksud dalam hal ini adalah matematika sekolah. Matematika sekolah terdiri dari bilangan dan logika, aljabar, geometri, trigonometri, kalkulus, dan statistika. Rendahnya pemahaman matematika mahasiswa meliputi berbagai hal yang terdiri dari fakta, konsep, prinsip, dan pemecahan masalah.

Banyak faktor yang mempengaruhi keberhasilan belajar matematika. Faktor- faktor tersebut diantaranya adalah sikap, minat, motivasi dan kebiasaan belajar. Sikap menurut Hartati (2013:333) berpengaruh positif terhadap hasil belajar matematika siswa. minat dan kebiasaan belajar menurut Siagian (2015:130) berpengaruh positif terhadap hasil belajar matematika. selain itu Saleh (2014:137) menyatakan bahwa motivasi berpengaruh positif terhadap hasil belajar. Beberapa faktor yang telah disebutkan merupakan faktor afektif yang mempengaruhi keberhasilan dalam belajar matematika.

Banyak penelitian yang menunjukkan bahwa sikap, minat, motivasi dan kebiasaan belajar berpengaruh positif terhadap keberhasilan belajar. Hal ini berarti sikap positif, minat yang tinggi, motivasi yang tinggi, dan kebiasaan belajar yang baik tentu akan memberikan hasil belajar matematika yang baik. Akan tetapi penelitian menunjukkan bahwa mahasiswa yang memiliki pemahaman matematika kurang sekali ternyata memiliki sikap yang positif terhadap matematika, minat yang tinggi terhadap matematika, motivasi belajar yang tinggi dan memiliki kebiasaan belajar yang baik. Spekulasi lain yang dapat ditarik dari uraian diatas adalah terdapat faktor lain yang dalam hal ini yang menentukan keberhasilan belajar matematika (Sripatmi at.al.2018).

Rendahnya pemahaman matematika sekolah dapat ditingkatkan dan dipercepat dengan pembelajaran yang melibatkan media pembelajaran (Fathurrohman \& Sutikno, 2007: 67). Uraian tersebut menjelaskan bahwa media pembelajaran merupakan suatu hal yang penting dalam pembelajaran matematika terutama dalam menigkatkan pemahaman siswa terkait dengan materi baik itu konsep, prinsip dalam matematika.

Buku referensi media pembelajaran matematika merupakan suatu hal sangat diperlukan akan tetapi keberadaannya sangat minim sehingga guru-guru dalam mengajar matematika tidak dapat mengembangkan media pembelajaran secara mandiri. Berdasarkan hasil survey terkait dengan penggunaan alat peraga oleh guru-guru SMP dan SMA di 5 kabupaten dan kota diperoleh 92,8\% guru- guru menyatakan materi matematika yang diajarkan memerlukan Media. 21,4\% guru-guru selama mengajar tidak 
pernah menggunakan media dalam pembelajaran matematika dan sebanyak $67,8 \%$ guruguru menggunakan Media 1-3 kali dalam satu semester.

Survey lebih lanjut dilakukan dalam rangka mendapatkan informasi terkait penyebab guru-guru tidak menggunakan media sehingga selanjutnya dapat ditemukan solusi. Hasil survey menunjukkan $82,2 \%$ guru-guru tidak pernah mengikuti pelatihan tentang media, 85,7\% guru-guru tidak memiliki buku referensi tentang media pembelajaran matematika dan 50\% guru-guru kesulitan menyiapkan media pembelajaran yang dapat membantu pembelajaran.

Respon guru terkait dengan pernyataan apakah guru-guru memerlukan buku referensi yang dapat memberikan contoh Media Pembelajran matematika untuk materi Sekolah Menengah Pertama diperoleh 89,3\% menyatakan sangat butuh. Sehingga berdasarkan uraian masalah dan faktor penyebab masalah maka akan dikembangkan buku referensi Media Pembelajaran Matematika untuk materi sekolah menengah pertama.

\section{METODE PELAKSANAAN}

Tujuan dari penelitian ini adalah untuk mengembangkan buku referensi media pembelajaran Matematika untuk jenjang sekolah menengah pertama. Oleh karena bertujuan untuk mengembangkan produk, jenis penelitian yang digunakan adalah Design Research (Plomp, 2007). Adapun langkah penelitian yang digunakan menyesuaikan dari desain Reeves (2006).

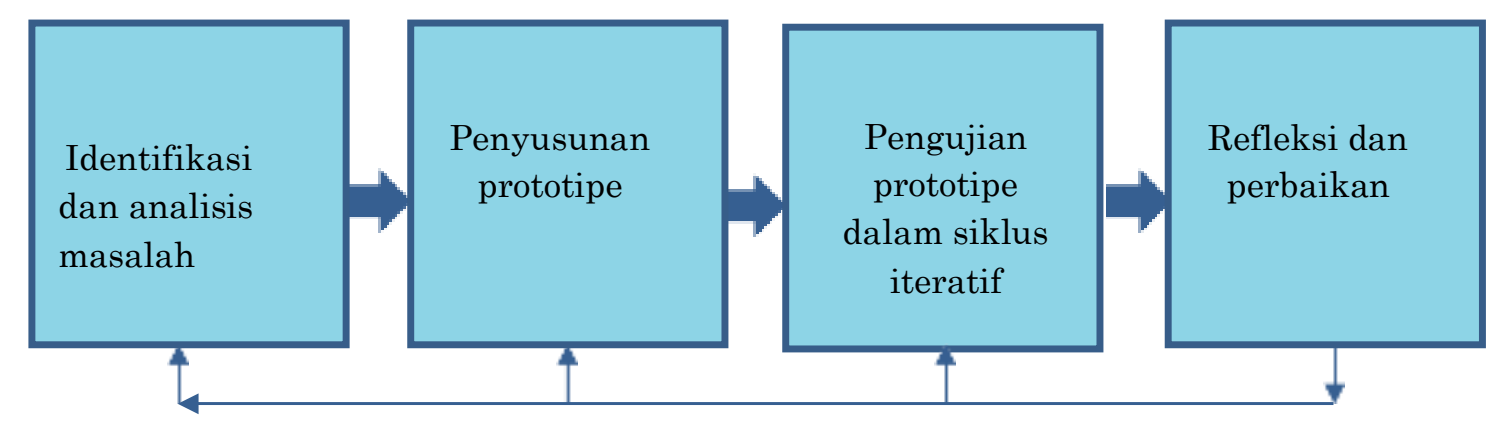

Gambar 2.1. Design Research

Gambar 2.1 menunjukkan adanya siklus yang berulang sebagai ciri dari penelitian dengan jenis design research. Prototype yang pertama disusun disebut dengan Prototipe I yang disusun berdasarkan hasil dari identifikasi dan analisis masalah atau kebutuhan dari kondisi yang ada saat ini terkait dengan keberadaan buku referensi media pembelajaran. prototype I tersebut kemudian diuji coba tahap I untuk mengevaluasi apakah produk yang dirancang dapat digunakan sesuai harapan. Hasil uji coba akan digunakan untuk memberikan masukan terkait dengan perbaikan yang diperlukan. Proses ini terus berlanjut hingga data menjadi jenuh dan siap diuji coba pada subjek yang lebih luas. 
Nieven (2007) membedakan dua jenis evaluasi pada design research ke dalam evaluasi formatif dan evaluasi sumatif. Pada tahap pengembangan produk, evaluasi formatif dilakukan dengan menguji validitas isi, validitas konstruk, kepraktisan dan efektivitas produk. Sementara itu Evaluasi Sumatif adalah pengujian dengan subjek yang lebih luas yang bertujuan untuk mengevaluasi transferability dari produk yang dikembangkan. Akan tetapi karena keterbatasan waktu, pada penelitian ini pengujian yang dilakukan hanya sampai pada validitas isi pada tahapan Evaluasi Formatif.

Pengumpulan data dan analisis data dalam penelitian ini disesuaikan dengan kebutuhan sesuai dengan tahapan pada design research sebagaimana pada Tabel 2.1.

Tabel 2.1. Metode Pengumpulan dan Analisis Data Penelitian

\begin{tabular}{|c|c|c|c|c|}
\hline No & Tahapan & $\begin{array}{l}\text { Data yang } \\
\text { Dibutuhkan }\end{array}$ & $\begin{array}{l}\text { Metode Pengumpulan } \\
\text { Data }\end{array}$ & $\begin{array}{l}\text { Metode Analisis } \\
\text { Data }\end{array}$ \\
\hline 1 & $\begin{array}{l}\text { Identifikasi } \\
\text { Masalah dan } \\
\text { Analisis } \\
\text { Kebutuhan }\end{array}$ & $\begin{array}{l}\text { Kebutuhan guru } \\
\text { dan calon guru } \\
\text { sekolah } \\
\text { menengah } \\
\text { pertama pada } \\
\text { buku referensi } \\
\text { Media } \\
\text { Pembelajaran } \\
\text { Ketersediaan } \\
\text { buku referensi } \\
\text { Media } \\
\text { Pembelajaran } \\
\text { yang } \\
\text { beredar luas. }\end{array}$ & $\begin{array}{l}\text { Angket yang ditujukan } \\
\text { kepada guru dan calon } \\
\text { guru matematika tingkat } \\
\text { SMP dan SMA (sederajat) } \\
\text { yang berada di Kota } \\
\text { Mataram }\end{array}$ & $\begin{array}{l}\text { Metode } \\
\text { gabungan } \\
\text { (Deskriptif } \\
\text { Kuantitatif } \\
\text { dan } \\
\text { Deskriptif } \\
\text { Kualitatif }\end{array}$ \\
\hline 2 & $\begin{array}{l}\text { Pengembangan } \\
\text { Prototipe dan } \\
\text { Evaluasi } \\
\text { Formatif }\end{array}$ & Validitas Isi & $\begin{array}{l}\text { Kajian literatur untuk } \\
\text { membandingkan } \\
\text { kebutuhan (kondisi ideal) } \\
\text { buku referensi Media } \\
\text { Pembelajaran } \\
\text { dengan keadaan (kondisi } \\
\text { nyata) saat ini }\end{array}$ & $\begin{array}{l}\text { Deskriptif } \\
\text { Kualitatif }\end{array}$ \\
\hline & & & $\begin{array}{l}\text { Review Ahli (dosen dan } \\
\text { guru matematika } \\
\text { SMP) }\end{array}$ & $\begin{array}{l}\text { Deskriptif } \\
\text { Kuantitatif }\end{array}$ \\
\hline
\end{tabular}

\section{HASIL DAN PEMBAHASAN}

Pengembangan buku referensi media pembelajaran matematika untuk sekolah menengah pertama (SMP) diawali dengan survey masalah yang dihadapi guru-guru matematika dalam membelajarkan matematika di sekolah menengah pertama. Berdasarkan hasil survey terkait dengan penggunaan alat peraga oleh guru-guru SMP dan SMA di 5 kabupaten dan kota diperoleh 92,8\% guru- guru menyatakan materi matematika yang diajarkan memerlukan Media. 21,4\% guru-guru selama mengajar tidak pernah menggunakan media dalam pembelajaran matematika dan sebanyak $67,8 \%$ guruguru menggunakan Media 1-3 kali dalam satu semester. Survey lebih lanjut dilakukan 
dalam rangka mendapatkan informasi terkait penyebab guru-guru tidak menggunakan media sehingga selanjutnya dapat ditemukan solusi. Hasil survey menunjukkan $82,2 \%$ guru-guru tidak pernah mengikuti pelatihan tentang media, 85,7\% guru-guru tidak memiliki buku referensi tentang media pembelajaran matematika dan 50\% guru-guru kesulitan menyiapkan media pembelajaran yang dapat membantu pembelajaran. Berdasarkan hal tersebut maka yang dibutuhkan guru adalah media pembelajaran matematika baik itu pada jenjang sekolah menengah pertama maupun sekolah menengah atas.

Berdasarkan uraian masalah yang ada kemudian dilakukan analisis sebaran materi matematika di jenjang sekolah menengah pertama. Sekolah menengah pertama dipilih karena sikap siswa terhadap matematika ditentukan oleh bagaimana sikap siswa terhadap matematika pada jenjang sekolah menengah pertama. Hasil analisis diperoleh sebaran materi matematika pada jenjang sekolah menengah pertama. Analisis materi meliputi materi matematika kelas VII,VIII, dan IX semester I dan II yang meliputi : bilangan, aljabar, geometri dan pengukuran, statistika dan peluang. Dari setiap materi kemudian dianalisis materi materi apasaja yang memerlukan media pembelajaran. Hasil analisis menunjukkan beberapa materi yang memelukan media pembelajaran adalah operasi hitung Bilangan bulat dan pecahan, Persamaan Linear, Himpunan dan Diagram Venn, geometri, Nilai fungsi, sketsa grafik fungsi, kemiringan garis, pythagoras, lingkaran, garis singgung, lingkaran dalam dan lingkaran luar segitiga, sifat-sifat bangun ruang, kesebangunan, kekongruenan, tabung, kerucut, dan bola.

Berdasarkan materi-materi matematika yang memerlukan media pembelajaran kemudian dilakukan analisis media-media pembelajaran yang dapat diterapkan dalam pembelajaran matematika. Hasil analisis media yang dapat diterapkan dalam pembelajaran adalah media-media berbasis terknologi, hal ini didasarkan pada Keputusan Menteri Pendidikan dan Kebudayaan Nomor 1005/P/2020 yang berkaitan dengan mutu guru dan kulitas pembelajaran dan Permendikbud No 22 tahun 2016 BAB III yang menyatakan dalam pembelajaran sangat perlu menerapkan teknologi informasi dan komunikasi secara terintegrasi, sistematis, dan efektif sesuai dengan situasi dan kondisi. Media-media berbasis teknologi yang dapat diterapkan dalam pembelajaran matematika adalah sebagai berikut: peta konsep, power point informatif, power point interaktif, lembar kerja peserta didik, video pembelajaran, alat peraga, dan Geogebra.

Berdasarkan kerangka diatas maka disusun prototype buku referensi media pembelajaran matematika yang diperlukan bagi guru-guru SMP dengan kerangka sebagai berikut:

Daftar Isi

BAB I PENDAHULUAN

A. Pendahuluan.

B. Pengertian

C. Tujuan 
D. Fungsi

E. Manfaat

F. Jenis

G. Prinsip - prinsip memilih media pembelajaran

BAB II MEDIA PEMBELAJARAN

A. Peta Konsep

B. Power point informatif

C. Power point interaktif

D. Lembar Kerja Peserta Didik

E. Video pembelajaran

F. Alat peraga

BAB III PENGEMBANGAN MEDIA PEMBELAJARAN GEOGEBRA

A. Mengenal Geogebra

B. Mengembangkan Media dengan Geogebra

DAFTAR PUSTAKA

Berdasarkan kerangka buku referensi media pembelajaran matematika yang diperlukan bagi guru-guru SMP di Mataram yang telah diuraikan kemudian dilakukan pengembangan isi buku dengan merujuk pada sumber-sumber yang relevan. Isi buku yang disusun kemudian dilakukan analisis dan kajian untuk mengetahui lebih lanjut kriteria-kriteria yang perlu dipenuhi oleh sebuah buku yang sesuai dan tidak bertentangan dengan aturan-aturan yang ada. Hasil analisis dan kajian tersebut diperoleh bahwa terdapat 4 kriteria atau aspek yang diperlukan oleh buku referensi media pembelajaran matematika yang diperlukan bagi guru-guru SMP yaitu: aspek materi, bahasa, penyajian materi, dan kegrafikan. Berdasarkan 4 aspek tersebut kemudian dijadikan sebagai dasar dalam menentukan validitas dari buku referensi media pembelajaran matematika yang diperlukan bagi guru-guru SMP.

Aspek materi yang berkaitan dengan keakuratan materi, kemutakhiran data dan konsep, serta dapat mendukung pencapaian tujuan pendidikan nasional. Mendorong timbulnya kemandirian dan inovasi, mampu memotivasi untuk mengembangkan dirinya, Menggunakan sumber materi yang benar secara teoritik dan empiric. Aspek bahasa berkaitan dengan (1) Penggunaan bahasa (ejaan, kata, kalimat, dan paragraf) tepat, lugas, jelas, serta, Penggunaan bahasa sesuai dengan tingkat perkembangan usia, (2) Ilustrasi materi, baik teks maupun gambar sesuai dengan tingkat perkembangan usia pembaca dan mempu memperjelas materi/konten, (3) Bahasa yang digunakan komunikatif dan informatif sehingga pembaca mampu memahami pesan positif yang disampaikan, (4) Bahasa yang digunakan memiliki ciri edukatif, santun, etis, dan estetis sesuai dengan tingkat perkembangan usia, (5) Judul buku dan judul bagian-bagian materi/konten buku harmonis/selaras, menarik, mampu menarik minat untuk membaca, dan tidak provokatif. Aspek penyajian materi berkaitan dengan (1) Materi buku disajikan secara menarik (runtut, koheren, lugas, mudahdipahami, dan interaktif), sehingga keutuhan makna yang ingin disampaikan dapat terjaga dengan baik, (2) 
Ilustrasi materi, baik teks maupun gambar menarik sesuai dengan tingkat perkembangan usia pembaca dan mampu memperjelas materi/konten serta santun, (3) Penggunaan ilustrasi untuk memperjelas materi tidak mengandung unsur pornografi, paham ekstrimisme, radikalisme, kekerasan, SARA, bias gender, dan tidak mengandung nilai penyimpangan lainnya, Penyajian materi dapat merangsang untuk berpikir kritis, kreatif, dan inovatif, (4) Penyajian materi menarik sehingga menyenangkan bagi pembacanya dan dapat menumbuhkan rasa keingintahuan yang mendalam. Aspek kegrafikan berkaitan dengan (1) Ukuran buku sesuai dengan tingkat perkembangan usia dan materi/konten buku, (2) Pemberian warna pada unsur tata letak harmonis dan dapat memperjelas fungsi, (3) Penggunaan huruf dan ukuran huruf disesuaikan dengan tingkat perkembangan usia, (4) Ilustrasi yang digunakan mampu memperjelas pesan yang ingin disampaikan

Kerangka materi matematika berdasarkan analisis yang telah dilakukan menjadi dasar dalam menentukan kriteria buku referensi media pembelajaran matematika yang diperlukan bagi guru-guru SMP. Kriteria dalam hal ini adalah mencakup media-media yang diperlukan yaitu peta konsep, power point informatif, power point interaktif, lembar kerja peserta didik, video pembelajaran, alat peraga, dan Geogebra dan aspek-aspek lain dari buku tersebut yang meliputi 4 aspek yaitu aspek materi, bahasa, penyajian materi, dan kegrafikan.

Peta konsep adalah perangkat skematik untuk merepresentasikan sekumpulan makna konsep yang tertanam dalam kerangka proposisi (Novak dan Gowin, 1984). Pemetaan konsep merupakan teknik yang membuat Anda mengerti hubungan antar ide-ide dengan menciptakan peta hubungan secara visual (Rahman, 2016). Manfaat peta konsep dalam pembelajaran matematika adalah Memahami konsep dan hubungan di antar konsep, dan Menghubungkan pengetahuan baru dengan yang lama. Power point informatif adalah suatu program komputer yang dapat digunakan untuk melakukan presentasi dengan tujuan agar pendengar atau audience dapat menangkap dan memahami informasi yang disampaikan dengan baik. Manfaat dari penggunaan PPt informatif (Abubakar et al., 2021; Chen, 2012) Memberi gambaran singkat tentang urutan pengorganisasian konten pembelajaran pada peserta didik. Power point interaktif adalah presentasi yang memungkinkan terjadinya interaksi dua arah antara pebelajar dengan pengajar maupun antara pebelajar dengan komputer. Interaksi ini timbul karena pada presentasi interaktif, informasi tidak disajikan secara monoton dimana materi seluruhnya diberikan dalam lembar presentasi melainkan diberikan jeda dan kesempatan untuk melakukan eksplorasi sehingga pebelajar dapat membangun pemahamannya.

Lembar kerja peserta didik (LKPD) merupakan kumpulan dari lembaran yang berisikan kegiatan peserta didik yang memungkinkan peserta didik melakukan aktivitas nyata dengan objek dan persoalan yang dipelajari. Video Pembelajaran adalah media pembelajaran yang menggunakan teks, gambar, suara, dan animasi untuk menyampaikan isi materi ajar dari sumber belajar ke pebelajar (individu atau kelompok), 
yang dapat merangsang pikiran, perasaan, perhatian, minat pebelajar, dapat menangkap, memproses, dan menyusun kembali informasi visual atau verbal sedemikian rupa sehingga proses belajar (di dalam/di luar kelas) menjadi lebih efektif. Alat peraga merupakan suatu perangkat benda kongkret yang dirancang, dibuat, dihimpun, atau disusun secara sengaja yang digunakan untuk membantu menanamkan atau mengembangkan konsep-konsep atau prinsip-prinsip dalam matematika. Dengan alat peraga hal-hal yang abstrak itu dapat disajikan dalam bentuk model, dimana model tersebut berupa benda kongkrit yang dapat dilihat, dipegang, diputarbalikkan sehingga mudah dipahami dan mengandung atau membawakan ciri-ciri dari konsep yang dipelajari.

GeoGebra adalah software gratis yang dikembangkan oleh Markus Hohenwarter sejak tahun 2001. Geogebra berfungsi sebagai media pembelajaran yang memberikan pengalaman visual kepada siswa dalam berinteraksi dengan konsep-konsep. Dengan tampilan yang variatif dan menarik, serta kemudahan dalam memanipulasi berbagai objek diharapkan dapat meningkatkan minat siswa sekaligus dapat meningkatkan efektivitas pembelajaran matematika.

Setelah kerangka materi ditentukan maka selanjutnaya mengembangkan aspek-aspek yang perlu diperhatikan dalam penyusunan buku referensi yaitu aspek materi yang berkaitan dengan keakuratan materi, kemutakhiran data dan konsep, serta dapat mendukung pencapaian tujuan pendidikan nasional. Mendorong timbulnya kemandirian dan inovasi, Mampu memotivasi untuk mengembangkan dirinya, Menggunakan sumber materi yang benar secara teoritik dan empiric.

Aspek bahasa, bahasa berperan dalam mengkomunikasikan pikiran dan pengetahuan. Beberapa hal yang berkaitan dengan bahasa adalah (1) Penggunaan bahasa (ejaan, kata, kalimat, dan paragraf) tepat, lugas, jelas, serta, (2) Penggunaan bahasa sesuai dengan tingkat perkembangan usia, (3) Ilustrasi materi, baik teks maupun gambar sesuai dengan tingkat perkembangan usia pembaca dan mampu memperjelas materi/konten, (4) Bahasa yang digunakan komunikatif dan informatif sehingga pembaca mampu memahami pesan positif yang disampaikan, (5) Bahasa yang digunakan memiliki ciri edukatif, santun, etis, dan estetis sesuai dengan tingkat perkembangan usia, Judul buku dan judul bagian-bagian materi/konten buku harmonis/selaras, menarik, mampu menarik minat untuk membaca, dan tidak provokatif.

Aspek penyajian materi berkaitan dengan (1) Materi buku disajikan secara menarik (runtut, koheren, lugas, mudahdipahami, dan interaktif), sehingga keutuhan makna yang ingin disampaikan dapat terjaga dengan baik, (2) Ilustrasi materi, baik teks maupun gambar menarik sesuai dengan tingkat perkembangan usia pembaca dan mampu memperjelas materi/konten serta santun, (3) Penggunaan ilustrasi untuk memperjelas materi tidak mengandung unsur pornografi, paham ekstrimisme, radikalisme, kekerasan, SARA, bias gender, dan tidak mengandung nilai penyimpangan lainnya, (4) Penyajian materi dapat merangsang untuk berpikir kritis, kreatif, dan 
inovatif, (50 Penyajian materi menarik sehingga menyenangkan bagi pembacanya dan dapat menumbuhkan rasa keingintahuan yang mendalam.

Aspek kegrafikan berkaitan dengan (1) Ukuran buku sesuai dengan tingkat perkembangan usia dan materi/konten buku, (2) Pemberian warna pada unsur tata letak harmonis dan dapat memperjelas fungsi, (3) Penggunaan huruf dan ukuran huruf disesuaikan dengan tingkat perkembangan usia, (4) Ilustrasi yang digunakan mampu memperjelas pesan yang ingin disampaikan.

\section{SIMPULAN}

Berdasarkan hasil analisis dan kajian maka diperoleh kesimpulan yaitu kriteria buku referensi media pembelajaran matematika yang diperlukan bagi guru-guru SMP di Mataram adalah memuat media-media yang mampu membantu guru matematika dalam meningkatkan pemahaman yang baik terhadap siswa pada materi-materi operasi hitung bilangan bulat dan pecahan, persamaan linear, himpunan dan diagram Venn, geometri, nilai fungsi, sketsa grafik fungsi, kemiringan garis, pythagoras, lingkaran, garis singgung, lingkaran dalam dan lingkaran luar segitiga, sifat-sifat bangun ruang, kesebangunan, kekongruenan, tabung, kerucut, dan bola. Buku referensi tersebut harus memenuhi 4 aspek yaitu aspek materi, bahasa, penyajian materi, dan kegrafikan.

\section{REFERENSI}

Annisah, S. (2017). Alat peraga pembelajaran matematika. Tarbawiyah Jurnal Ilmiah Pendidikan, 11(01), 1-15.

Arifin, S. \& Kusrianto A. (2009). Sukses Menulis Buku Ajar \& Referensi. Jakarta: Grasindo.

Arsyad, A.(2007). Media Pembelajaran. Jakarta: Raja Grafindo Persada.

Fathurrohman, P. \& Sutikno, M.S. (2007). Strategi Belajar Mengajar Melalui Penanaman Konsep Umum dan Konsep Islam. Bandung: Refika Aditama.

Hartati, L. (2013). Pengaruh Gaya Belajar Dan Sikap Siswa Pada Pelajaran Matematika Terhadap Hasil Belajar Matematika. journal.lppmunindra.ac.id: Vol. 3 No. 3

Kalsum, U. (2016). Referensi sebagai layanan, referensi sebagai tempat: sebuah tinjauan terhadap layanan refernsi di perpustakaan perguruan tinggi. IQRA: Jurnal Ilmu Perpustakaan dan Informasi (e-Journal), 10(1), 132-146.

Kustandi, C., Sutjipto,B. (2011). Media Pembelajaran Manual dan Digital, Bogor: Ghalia Indonesia.

Lestari, N. (2020). Media Pembelajaran berbasis multimedia interaktif. Jawa tengah: Lakeisha

Murdiyanto, T., \& Mahatama, Y. (2014). Pengembangan Alat Peraga Matematika Untuk Meningkatkan Minat dan Motivasi Belajar Matematika Siswa Sekolah Dasar. Sarwahita, 11(1), 38-43.

Nieven, N. 2007. Formative Evaluation in Educational Design Research. In Plomp,T., \& Nieven, N. (Ed.), Proceedings of the Seminar Conducted at the East China Normal University (pp. 935). Shanghai: SLO. 
Piranti, L., \& Muliyati, D. (2016). Pengembangan Buku Referensi Berbasis Multi Representasi dengan Pendekatan Kontekstual pada Materi Kalor dan Termodinamika. Prosiding SNIPS2016, 495-500.

Plomp, T. (2007). Educational design research : An introduction. In Plomp, T., \& Nieven, N. (Ed.), Proceedings of the Seminar Conducted at the East China Normal University (pp. 9-35). Shanghai: SLO.

Prastowo, A. (2015). Panduan Kreatif Membuat Bahan Ajar inovatif. Yogyakarta: Diva Press.

Rahardi, A. (2004). Media pembelajaran. Jakarta:Dirjen Dikdasmen.

Reeves, T.C. (2006). Design research from a technology perspective. In: Van den Akker, J., Gravemeijer, K., McKenney, S., \& Nieveen, N. (Eds). (2006). Educational design research. London: Routledge, 52-66.

Riana, C., (2009). Media Pembelajaran. Jakarta: Kementerian RI.

Saleh, M. (2014). Pengaruh motivasi, faktor keluarga, lingkungan kampus dan aktif berorganisasi terhadap prestasi akademik. Jurnal Phenomenon, 4(2), 109-141.

Siagian, R. E. F. (2015). Pengaruh minat dan kebiasaan belajar siswa terhadap prestasi belajar matematika. Formatif: Jurnal Ilmiah Pendidikan MIPA, 2(2).

Sripatmi, Hikmah, N., Junaidi. (2018). Pemahaman Matematika Sekolah Mahasiswa Pendidikan Matematika FKIP Universitas Mataram. Penelitian. Mataram

Suherman, E. (2003). Strategi Pembelajaran Matematika Kontemporer, Bandung: JICA Jurusan Pendidikan Matematika UPI.

Sumiharsono, M. R.,Hasanah, A. (2017). Media Pembelajaran. Jember: CV Pustaka Abadi.

Sundayana, R. (2014). Media dan alat pearaga dalam pembelajaran matematika. Bandung: Alfabeta. 